This is the accepted version of Pradella, Lucia \& Rad, Taghdisi Rad, Sahar (2017) Libya and Europe: imperialism, crisis and migration. Third World Quarterly, 1-17. Publishe online 25 July, available at: http://dx.doi.org/10.1080/01436597.2017.1350819

Accepted version downloaded from SOAS Research Online: http://eprints.soas.ac.uk/24472/

\title{
Libya and Europe: Imperialism, Crisis and Migration
}

Lucia Pradella, Department of European and International Studies, Kings College London

Sahar Taghdisi Rad, School of Finance \& Management, SOAS University of London 
This is the accepted version of Pradella, Lucia \& Rad, Taghdisi Rad, Sahar (2017) Libya and Europe: imperialism, crisis and migration. Third World Quarterly, 1-17. Publishe online 25 July, available at: http://dx.doi.org/10.1080/01436597.2017.1350819

Accepted version downloaded from SOAS Research Online: http://eprints.soas.ac.uk/24472/

\section{Libya and Europe: Imperialism, Crisis and Migration}

This article examines the recent dynamics of European imperialism in Libya in the light of Marx's theory of the global reserve army of labour. It analyses the limited advance of Western imperialism in Libya in the decade before the 2011 uprisings, the interactions between local, regional and international forces during and after the NATO intervention, and, finally, the evolving migratory patterns from Libya. In this light, the instability along the southern and eastern Mediterranean coastline - a product of the uprisings and the forms of political reactions they unleashed - is simultaneously a security threat and a channel of migratory movements to European capitalism.

Keywords: Europe, imperialism, Libya, migration, reserve army of labour

\section{Introduction}

'We will fight to save the Euro', vowed President Sarkozy when the French initiated the war on Libya in March 2011. The British government made it explicit that a victory in Libya was crucial for British and European recovery. ${ }^{1}$ Yet only a few scholars linked the crisis in Europe to the military interventions in the Middle East and North Africa. The literature on the Eurozone crisis has increasingly focused on centre-periphery dynamics within the European Union, while the Marxist debate on the 'new imperialism' has largely dried up. David Harvey's more recent work does not address this question, while new studies of imperialism published in English by Claude Serfati, Andreas Bieler and Adam Morton do not discuss the Arab uprisings and their aftermath. 
This is the accepted version of Pradella, Lucia \& Rad, Taghdisi Rad, Sahar (2017) Libya and Europe: imperialism, crisis and migration. Third World Quarterly, 1-17. Publishe online 25 July, available at: http://dx.doi.org/10.1080/01436597.2017.1350819

Accepted version downloaded from SOAS Research Online: http://eprints.soas.ac.uk/24472/

Tony Norfield and John Smith focus on finance and industrial production restructuring respectively, not on war and migration. ${ }^{2}$

The lack of substantial debate on the more recent dynamics of European imperialism leads to an underestimation of the impact of southern workers' agency and popular resistance. In 2011, while the US embarked on withdrawing from Iraq and Afghanistan, the uprisings in Tunisia and Egypt soon spread throughout North Africa and the Middle East. In mid-February demonstrators throughout Libya demanded the fall of the regime. Because of the potential consequences of the uprisings both within and beyond the region, western leaders were deeply concerned and awaited an opportunity to intervene. This came with Gaddafi's brutal repression of the uprisings. Started under the aegis of the 'Responsibility to Protect' framework, the NATO intervention soon turned into a mission for regime-change, proving once again how the rhetoric of humanitarianism was a pretext for pursuing neo-colonial interests. The war served both economic and geopolitical goals, and exposed the divisions between US and European imperialism, and between European powers themselves.

Developing an analysis of the Libya intervention and its aftermath serves two purposes: first, to clarify the nature of imperialism today, and second, to cast light on some interpretations of events in Libya. Within the rather scant critical literature on Libya, on the one hand there are interpretations that focus on the western attempt to secure control on Libyan resources and get rid of a relatively progressive Gaddafi. On the other, there are interpretations that focus on the Gaddafi regime's repressive and neoliberal character but fail to take fully into account the extent to which outside interventions reflected the interests of the powers concerned. ${ }^{3}$ Our analysis seeks to overcome these limitations and highlight the complexity of how imperialism functions today involving 
This is the accepted version of Pradella, Lucia \& Rad, Taghdisi Rad, Sahar (2017) Libya and Europe: imperialism, crisis and migration. Third World Quarterly, 1-17. Publishe online 25 July, available at: http://dx.doi.org/10.1080/01436597.2017.1350819

Accepted version downloaded from SOAS Research Online: http://eprints.soas.ac.uk/24472/

as it does inter-state rivalries not just among western powers but also among Russia,

China and regional actors. In order to provide a full account, moreover, these rivalries need to be analysed against the backdrop of the global dynamics of capitalist accumulation and the development of the reserve army of labour. This is, as we discuss in the following section, one of the main contribution of Marx's own conceptualisation of the link between capitalism and imperialism in Capital Volume 1. In the light of this analysis, the article discusses the limited advance of western imperialism in Libya in the decade before the uprisings; the interactions between local, regional and international forces during and after the NATO intervention, and, finally, the development of the reserve army of labour and the evolving patterns of migration from Libya to Europe. The final section concludes.

\section{Capitalism, imperialism and crisis}

Marxist debates on imperialism start from the assumption that Marx's Capital focuses on a self-enclosed national economy in a specific historical phase of accumulation rather than on the overall tendency of the system as a totality. ${ }^{4}$ In analysing capital reproduction, however, Marx treats 'the whole world as one nation', anticipating Rosa Luxemburg's insight that 'if the analysis of the reproductive process actually intends not any single capitalist country but the capitalist world market, there can be no foreign trade: all countries are "home", ${ }^{5}$ Crucially, this allowed Marx to take structurally into account the international mobility of capital and labour-power in Capital Volume 1: an argument, advanced by Pradella $(2010,2013)$, which has been largely overlooked in the scholarship. Marx also identified the trend towards increasing firm sizes and growth of 'finance capital' that for Lenin characterise contemporary imperialism. ${ }^{6}$ By 
This is the accepted version of Pradella, Lucia \& Rad, Taghdisi Rad, Sahar (2017) Libya and Europe: imperialism, crisis and migration. Third World Quarterly, 1-17. Publishe online 25 July, available at: http://dx.doi.org/10.1080/01436597.2017.1350819

Accepted version downloaded from SOAS Research Online: http://eprints.soas.ac.uk/24472/

distinguishing concentration and centralisation of capital, Marx recognised the importance of mergers and acquisitions, the formation of joint stock companies, and the growth of a financial aristocracy less and less involved in the actual production process. Nevertheless, he deemed the isolation between 'capital in the production process' and 'capital-property, capital outside the production process and yielding interest of itself' to be the highest form of fetishism. The growth of the latter, in his view, enhanced the sectoral and geographical mobility of capital and the process of capitalist centralisation. ${ }^{7}$ This approach, therefore, rejects an exclusive focus on specific capitalist sectors (e.g., oil corporations, financial funds), and firmly situates imperialism within the overall, global dynamics of capitalist accumulation.

This interpretation of Marx's analysis of the relationship between capitalism and imperialism also contributes to debates on capital and the state ${ }^{8}$ by highlighting Marx's understanding of the close connection between internal and external aspects of state intervention. Significantly, Part 8 of Capital Volume 1 on the so-called primitive accumulation entails a critique of both western state-building and empire-building: it addresses both the processes of state-supported dispossession of communities aimed at securing land, resources, and labour-power for capitalist interests at home, and the role of colonialism, trade policies and war in concentrating the wealth invested in industrial production. These methods, for Marx, do not belong only in a pre-history of capital, but are permanent. As in the example of Britain, France and the US during the Chinese wars, while cooperating to extend their spheres of influence, imperialist states also increase their reciprocal rivalries. Indeed, for Marx the 'commercial war of the European nations, which has the globe as its battlefield [...]' was 'still going on in the shape of the Opium Wars against China. ${ }^{99}$ As evident in periods of economic crises, the 
This is the accepted version of Pradella, Lucia \& Rad, Taghdisi Rad, Sahar (2017) Libya and Europe: imperialism, crisis and migration. Third World Quarterly, 1-17. Publishe online 25 July, available at: http://dx.doi.org/10.1080/01436597.2017.1350819

Accepted version downloaded from SOAS Research Online: http://eprints.soas.ac.uk/24472/

link between capitals and their national governments have actually strengthened over time.

Marx, in our view, took two steps further with respect to Lenin and contemporary theorists of imperialism. First, he grounded his analysis of imperialism in his value theory. Following processes of so-called primitive accumulation, capital accumulation as such tends to concentrate higher value added production in the system's most competitive centres leading to a forced specialisation of dependent countries in lowervalue added sectors, the repatriation of profits extracted in these countries, and forms of unequal exchange between nations with different productivity levels. These forms of uneven and combined development are reflected in differential forms of labour exploitation in the nations involved. Marx, secondly, understood evolving inter-state relations against this global backdrop. In his view, economic and military expansionism - and the resulting growth of the relative surplus population and investment opportunities - were powerful factors raising the rate of exploitation and countervailing the tendency of the rate of profit to fall. ${ }^{10}$ Marx thus conceptualised the reserve army in truly global terms and identified the permanent role of the state in its expansion. As he incisively puts it, 'as soon as (in the colonies, for example) adverse circumstances prevent the creation of an industrial reserve army [...], capital, along with its platitudinous Sancho Panza, rebels against the "sacred" law of supply and demand, and tries to make up for its inadequacies by forcible means. ${ }^{, 11}$ Crucially, social relations in the colonies reacted back on England itself: primary production by Irish impoverishment farmers, for example, was one of the pillars of English industry, as was Irish immigration in England and resulting working class dynamics. ${ }^{12}$ 
This is the accepted version of Pradella, Lucia \& Rad, Taghdisi Rad, Sahar (2017) Libya and Europe: imperialism, crisis and migration. Third World Quarterly, 1-17. Publishe online 25 July, available at: http://dx.doi.org/10.1080/01436597.2017.1350819

Accepted version downloaded from SOAS Research Online: http://eprints.soas.ac.uk/24472/

This framework is relevant to our analysis for two main reasons. First, it illuminates the links between crisis and imperialism, highlighting both the competitive character of the collaboration between the main imperialist powers and the autonomous interests of nonimperialist states. More specifically, since 2007/8 a persisting crisis of profitability intertwined with the specific problems faced by countries with different productive specialisations led to a sharp decline of the EU's share of world manufacturing output value, matched by a significant increase of China's share. ${ }^{13}$ Now the largest manufacturing and exporting power in the world and a major anchor of finance, China has built networks in the rest of the global South counterbalancing western influence. ${ }^{14}$ Control over Africa and the Middle East has thus become increasingly vital to western powers both for economic reasons and for the 'political leverage' such control gives visà-vis Asian countries. ${ }^{15}$ As Claude Serfati and Alex Callinicos highlight, rather than leading to the emergence of a transnational capitalist class, the development of European institutions reinforced the imperialism of its stronger member-states. ${ }^{16}$ Even after the creation of the European Security and Defence Policy, in Africa the EU militarily relied on France, and France was concerned by the US 2007 launch of AFRICOM despite the latter's goal of containing China's influence. ${ }^{17}$ While collaborating with the West, moreover, Gaddafi was also pursuing Libya's own national interests and alliances. As several scholars convincingly argued, the NATO intervention was aimed at getting rid of Gaddafi in order to gain control of Libyan natural and financial wealth, cut back Libya's influence in Africa, and limit China's access to longterm oil imports. ${ }^{18}$

Secondly, Marx's understanding of inter-states rivalries as based on the differential exploitation of a global working class avoids analysing imperialism in mere 
This is the accepted version of Pradella, Lucia \& Rad, Taghdisi Rad, Sahar (2017) Libya and Europe: imperialism, crisis and migration. Third World Quarterly, 1-17. Publishe online 25 July, available at: http://dx.doi.org/10.1080/01436597.2017.1350819

Accepted version downloaded from SOAS Research Online: http://eprints.soas.ac.uk/24472/

(geo)political and military terms. Despite diverging positions on the relationship between capital and the state, Harvey, Callinicos and neo-Gramscian contributions alike do not sufficiently link the analysis of crisis, imperialism, and global class relations. John Bellamy Foster et al.'s insightful study of the global reserve army of labour mainly focuses on production restructuring in East Asia. ${ }^{19}$ But other factors swelling the ranks of the reserve army of labour are the mass impoverishment and displacement caused by economic and military imperialism in the global South. Looking at imperialism as a system of labour exploitation is crucial to placing workers' and popular agency at the centre of analysis. This helps identify the real grievances that fuelled the Libyan uprising and its potential conjunction with the movements in the region and beyond: a conjunction that the NATO intervention sought to prevent. Post-2011 Libyan dynamics, moreover, are not reducible to the interests of the main imperialist and regional actors, but show the continuing importance of domestic social forces.

This approach also sheds light on the ways in which these intertwined social and political relations react back on Europe. As several scholars have argued, as in Marx's example of Ireland mentioned above, the dynamics of the global reserve army of labour and 'the spectacle of militarised border enforcement' impact on political and social relations within Europe itself. ${ }^{20}$ Border controls do not stop immigration, but make it more dangerous and expensive, and immigrants more vulnerable, including to human smugglers. Borders function as a filtering device for prospective immigrants and expulsions push them either to move to other EU countries or find jobs in the informal sector. ${ }^{21}$ Immigration restrictions thus reinforce the process of labour market segmentation and precarisation in receiving countries, contributing to restoring profitability and competitiveness in a changing geography of accumulation. The 
This is the accepted version of Pradella, Lucia \& Rad, Taghdisi Rad, Sahar (2017) Libya and Europe: imperialism, crisis and migration. Third World Quarterly, 1-17. Publishe online 25 July, available at: http://dx.doi.org/10.1080/01436597.2017.1350819

Accepted version downloaded from SOAS Research Online: http://eprints.soas.ac.uk/24472/

narrative of a 'migration crisis', moreover, seeks to shift attention away from imperialism and prevent the international conjunction of labour and social struggles.

\section{The limited advance of Western imperialism in Libya (1999-2011)}

Looking at imperialism as a system of accumulation that operates internationally helps shed light on the recent dynamics of European imperialism in Libya. Despite attempts to diversify its economy, by 2011 Libya was still highly dependent on oil exports. With Africa's largest proven oil reserves, oil constituted almost 65 per cent of Libya's GDP, 96 per cent of its exports, and 98 per cent of its government revenues. The bulk of Libyan exports have been directed towards European countries, which benefitted from Libya's geographical proximity and the quality of its oil. ${ }^{22}$ While in the period of sanctions Libya was the operational focus for many European companies (especially Italian, German, Spanish, Austrian and Turkish), the suspension and progressive lifting of sanctions since 1999 led to vigorous competition between western oil companies for the control of Libyan resources. After 9/11, moreover, the Libyan leadership attempted to warm up relations with the US, joining the 'coalition of the willing' in the 'war on terror' and opening the door to US oil companies. ${ }^{23}$ A 'reform-minded' elite (led by Saif Gaddafi) implemented an IMF-endorsed liberalisation and privatisation programme, and revived the Export and Production Sharing Agreements (EPSAs). By 2007 more than forty international oil and gas companies had returned to Libya, including British Petroleum. ${ }^{24}$ Although it did not do very well, France's diplomatic and economic ties with Libya were improving, and French companies were seeking to secure control over Libya's water resources, the largest in Africa. The German consortium Desertec, moreover, was trying to enter Libya's solar energy sector. ${ }^{25}$ 
This is the accepted version of Pradella, Lucia \& Rad, Taghdisi Rad, Sahar (2017) Libya and Europe: imperialism, crisis and migration. Third World Quarterly, 1-17. Publishe online 25 July, available at: http://dx.doi.org/10.1080/01436597.2017.1350819

Accepted version downloaded from SOAS Research Online: http://eprints.soas.ac.uk/24472/

In the period that Luis Martinez calls the 'conversion' of the Libyan leadership, the EPSAs were used to maintain a balance between western and Chinese, Russian, Brazilian, Turkish and other corporate entities. In 2003 economic cooperation between Libya and China entered a new phase: seven years later Libya was one of China's top oil exporters and one of the largest importers of Chinese foreign investment and technology, with seventy-five Chinese enterprises engaged in infrastructural and housing projects worth nearly \$20 billion. Russia resumed economic links with Libya in 2008, cancelling Libya's Soviet-era debt in exchange for contracts for Russian companies, including arms deals and the construction of a rail line between Benghazi and Sirte. ${ }^{26}$ In 2006 Libyan reformers established a Sovereign Wealth Fund, the Libyan Investment Authority (LIA), to diversify their holdings of foreign reserves and gain greater control over the government's investment portfolio. Thanks to GDP growth and rising oil prices, by the end of 2010 the LIA had amassed over $\$ 53$ billion in assets held around the world and was consolidating its position in the Gulf. In December 2010 the Central Bank of Libya took the controlling position in the Bahrain-based Arab Banking Corporation $(\mathrm{ABC})$, generating alarm among many political leaders in the Gulf Cooperation Council (GCC). ${ }^{27}$

Two days before the February 17 'Day of Rage', the IMF congratulated the Libyan government for its 'ambitious programme to privatise banks and develop the nascent financial sector. ${ }^{, 28}$ But as soon became clear this was not a path Libya was at peace with. Gaddafi's old guard maintained a tight grip on the process of economic liberalization, seeking to ensure political stability by redistributing oil rent through state subsidies and public services. From the late 1980s onwards, this redistributive system, which had quadrupled Libya's per capita income between 1969 and 1979, had come 
This is the accepted version of Pradella, Lucia \& Rad, Taghdisi Rad, Sahar (2017) Libya and Europe: imperialism, crisis and migration. Third World Quarterly, 1-17. Publishe online 25 July, available at: http://dx.doi.org/10.1080/01436597.2017.1350819

Accepted version downloaded from SOAS Research Online: http://eprints.soas.ac.uk/24472/

under growing pressure because of US and UN sanctions combined with falling oil prices. In the 2000 s oil revenues were increasingly invested in international financial markets rather than in production and basic services, or appropriated by the ruling elites and invested abroad, especially in Sub-Saharan Africa. ${ }^{29}$ The large but declining public sector continued to be the main source of employment for Libyan citizens, but its monthly wages had been frozen at \$180-215 for two decades and rose only marginally in 2007. In 2006 the government adopted a programme to transfer 400,000 government employees out of the public sector; by 2009 , however, less than half of them had successfully moved into the private sector. In 2010, unemployment levels were estimated at 30 per cent, youth unemployment at 48 per cent. $^{30}$

Despite popular discontent at the lack of job opportunities, Gaddafi actively encouraged immigration from Sub-Saharan Africa and the Middle East. A large proportion of jobs in the oil, construction, agricultural and services sectors were carried out by immigrants. In 2011, with a population of 6.5 million citizens, there were at least 2.5 million immigrants in Libya, mainly from West Africa, the Horn of Africa, the Middle East and South Africa. Immigration fuelled labour market competition in the low-wage sector of the economy: black Africans performed the least-paid jobs compared to Arabicspeaking immigrants or those who could enter legally, and came under increasing attack as institutionalised racism and popular discontent grew. ${ }^{31}$ Trade unions had long been banned, and all forms of political and community organisation were harshly repressed. ${ }^{32}$ Gaddafi also adopted a strategy of uneven development targeting 'rebel' regions. Although possessing 80 per cent of Libya's oil reserves, for example, Cyrenaica was economically and politically marginalised, and this fuelled an Islamist opposition. ${ }^{33}$ 
This is the accepted version of Pradella, Lucia \& Rad, Taghdisi Rad, Sahar (2017) Libya and Europe: imperialism, crisis and migration. Third World Quarterly, 1-17. Publishe online 25 July, available at: http://dx.doi.org/10.1080/01436597.2017.1350819

Accepted version downloaded from SOAS Research Online: http://eprints.soas.ac.uk/24472/

Despite these developments, Libya was not fully aligned to the interests of western imperialism. The country witnessed only moderate economic liberalisation in the decade prior to the uprisings. For western leaders, the neoliberal faction of the Libyan leadership was too weak and Gaddafi an obstacle to the desired economic reforms. ${ }^{34}$ In 2007 and 2008 Gaddafi had forced major oil and gas corporations to renegotiate their contracts, and in January 2009 threatened to nationalise the industry. WikiLeaks cables prove that western states and companies were collaborating with Gaddafi, while working to build up information and resources to remove him. ${ }^{35}$ Another source of tension was Libya's economic and political network in Africa. In the decade prior to the uprisings, Gaddafi paid increasing attention to economic diversification, and began once again to look south in search of markets and political alliances. One of his major goals was to reach food and water self-sufficiency. He wanted to complete the Great ManMade River project, a \$30-billion irrigation project initiated in 1982 to transport water from the south of Libya to about 70 per cent of the population. ${ }^{36}$ In 2006 , moreover, the LIA established a $\$ 5.2$ billion Libyan African Investment Portfolio that by 2011 had investments in 31 African countries in key sectors like telecommunications, mining, manufacturing, hospitality, raw-material processing and water bottling. During the 2005 and 2009 African Union Summits Gaddafi emphasised his plans to establish an African Central Bank, an African Monetary Fund and an African Court of Justice to challenge their western counterparts: a move that rang alarm bells in Washington. In 2008, he also attempted to block the idea of a Mediterranean Union mooted by France to circumvent the African Union and the Arab League. ${ }^{37}$

\section{Continuing politics by other means}


This is the accepted version of Pradella, Lucia \& Rad, Taghdisi Rad, Sahar (2017) Libya and Europe: imperialism, crisis and migration. Third World Quarterly, 1-17. Publishe online 25 July, available at: http://dx.doi.org/10.1080/01436597.2017.1350819

Accepted version downloaded from SOAS Research Online: http://eprints.soas.ac.uk/24472/

The 2011 uprising and Gaddafi's repressive response gave the Western powers the opportunity to intervene to reshape Libya to conform more to their interests. But, as the theoretical framework we have outlined would predict, this intervention has been marked by the conflicts of interest among the major imperialist states, Russia, China and regional power actors. It has also been, at least partially, blunted by the initiatives of Libyan political forces, often acting in concert with rival outside powers.

In the wake of the global economic crisis Libya did not experience the same level of economic distress as other countries in the region. Both economic and political factors, however, help explain the origins of the uprisings: the lack of democracy, the failure of the state to diversify the economy, the worsening social conditions amidst the enrichment of the ruling family, the marginalization of Cyrenaica, and the inspiration from the movements in Tunisia and Egypt. ${ }^{38}$ As elsewhere, the Libyan uprisings started as an unarmed grass-roots movement, but the role of organised labour was much weaker than in Tunisia and Egypt. Brutal repression by Gaddafi's security forces, moreover, contributed to the rapid militarisation of the uprising, marginalising the youth and 'civil society' forces. Calls for an internationally enforced no-fly zone grew louder and a political leadership, the National Transition Council (NTC), was rapidly established. France - eager to take advantage of the crisis to establish itself in a country where other European states were ahead of it - was the first imperialist power to recognise the NTC and, along with the US, started bombing Libya even before a formal UN agreement. While Britain supported the move, Germany pulled out of any military operations. On 17 March, UN Security Council Resolution 1973 approved a no-fly zone and authorised a large coalition, including NATO and the Arab League, to 'take all necessary measures' except military occupation to protect civilians. The US ceded leadership to a 
This is the accepted version of Pradella, Lucia \& Rad, Taghdisi Rad, Sahar (2017) Libya and Europe: imperialism, crisis and migration. Third World Quarterly, 1-17. Publishe online 25 July, available at: http://dx.doi.org/10.1080/01436597.2017.1350819

Accepted version downloaded from SOAS Research Online: http://eprints.soas.ac.uk/24472/

French- and British-led NATO mission, with Qatar providing financial, military and media support and sending hundreds of special forces to Libya. ${ }^{39}$

The NATO intervention gave western powers an opportunity to try and co-opt the leadership of the rebellion, despite their limited influence over fighters' actions. ${ }^{40}$ In February the Libyan authorities started to move to divest their funds from their overexposure to British and US financial institutions, but their assets were frozen by the UK and the US governments; the latter froze more than \$30 billion funds earmarked for the establishment of the African Central Bank, African Monetary Fund and African Court of Justice. ${ }^{41}$ According to Campbell, since the Libyan leadership could retaliate by nationalising oil, one key objective of the bombings was to precipitate the exodus of workers from the economy. By the end of October 2011, 9,700 bombing missions, about 27,000 sorties, and an average of 150 air strikes per day were carried out, killing thousands of people and destroying Libyan infrastructure. ${ }^{42}$ Against the Laws of War preventing attacks on targets indispensable to the civilian population, NATO bombed Libya's Great Man-Made River's water pipeline near Brega and destroyed a pipeproducing factory. As UNICEF reported, this has provoked severe water scarcity since $2011 .^{43}$ Thousands of technicians and immigrant workers were killed, imprisoned or forced to leave the country. ${ }^{44}$ Many African immigrants tried to escape the violence of the rebels, who were enraged by reports of African mercenaries working for Gaddafi; others were forced into the deadly trip across the Mediterranean by Gaddafi himself, who threatened to flood Europe with Africans. ${ }^{45}$

Crucial to defeating Gaddafi, the NATO intervention inaugurated what the New York Times called a 'scramble for access to Libya's oil wealth' (22 August 2011). With the NTC consolidating itself, US and European officials coaxed investors not to miss the 
This is the accepted version of Pradella, Lucia \& Rad, Taghdisi Rad, Sahar (2017) Libya and Europe: imperialism, crisis and migration. Third World Quarterly, 1-17. Publishe online 25 July, available at: http://dx.doi.org/10.1080/01436597.2017.1350819

Accepted version downloaded from SOAS Research Online: http://eprints.soas.ac.uk/24472/

unique opportunity for oil and reconstruction contracts. This led to a hasty return of the major oil companies and a flurry of diplomatic visits by Turkish, French, Italian and British leaders. Seeking to salvage billions of dollars in contracts, in September China and Russia recognised the NTC. The killing of Gaddafi by Libyan militias with the support of western forces in October was to symbolise a radical change. While western powers attempted to establish control over the LIA leadership, the NTC announced its intention to review Libyan investments in the Middle East, Africa and around the world with the help of the World Bank. The IMF team that arrived in Libya in April 2012 recommended further economic liberalisation and privatisation, seizing down the public sector, and pushing down wages. ${ }^{46}$

While publicly rejecting the presence of western and UN troops, the NTC actually consented to British, Canadian and French security firms operating in the country and to US drone missions in eastern Libya. With oil revenues down and plans further to liberalise the economy, the NTC had little to offer to the population and to respond to the demands of the unemployed and the workers, as proved by the unsuccessful strikes at the Arabian Gulf Oil Company and at the Libyan Cement Company in April and May 2012. Instead, the NTC actively supported the armed groups' wave of retribution and victimisation of suspected Gaddafi supporters, and guaranteed immunity to 'revolutionaries' performing actions 'dictated by the February 17 Revolution', including war crimes and human rights violations (Law 38/2012). With no experienced trade union or left party to organise social discontent, tribal and regional divisions grew. ${ }^{47}$ The leaked western-backed map for Libya revealed that the UK, France and Italy supported the reintegration of select Gaddafi-era officials and bureaucrats, but Libyan activists and armed groups rejected this plan. ${ }^{48}$ Conflicts soon grew within the NTC 
This is the accepted version of Pradella, Lucia \& Rad, Taghdisi Rad, Sahar (2017) Libya and Europe: imperialism, crisis and migration. Third World Quarterly, 1-17. Publishe online 25 July, available at: http://dx.doi.org/10.1080/01436597.2017.1350819

Accepted version downloaded from SOAS Research Online: http://eprints.soas.ac.uk/24472/

between the liberals and the Libyan Muslim Brotherhood. Based on advice from their western allies, in April 2012 the liberals implemented a law banning parties 'based on religion or ethnicity or tribe', clearly targeted at the Muslim Brotherhood. Despite their poor electoral performance in the July elections for the General National Council (GNC), Islamist parties retained significant political influence, bolstered by the Islamist forces within the militias. ${ }^{49}$ In September the Ansar al-Sharia militia attacked the US diplomatic mission in Benghazi (apparently used by the CIA to smuggle weapons to anti-Assad rebels in Syria) and killed the US ambassador Christopher Stevens. ${ }^{50}$ This reinforced the US decision to pass on responsibility over transition to their European allies, but this proved challenging also because of the lack of unity among the Europeans. ${ }^{51}$ Under pressure from Islamist forces, moreover, in May 2013 the GNC issued the Political Isolation Law, banning from public office broad swaths of the population suspect of collaboration with the Gaddafi regime. ${ }^{52}$ The Muslim Brotherhood then took over the GNC, forming the Government of National Salvation based in Tripoli. This left a political vacuum that Khalifa Haftar, a renegade general who had spent the previous decades in exile, was able to fill. In May 2014 'Operation Dignity' defeated the Islamic militants in eastern Libya and Haftar gave his support to the newly-formed liberal-dominated government in Tobruk-Bayda. In the summer of 2014, the civil war prompted the withdrawal of a majority of international actors from Libya, including UK, US and French companies. ${ }^{53}$ The disintegration of the Libyan state created the space for the expansion of ISIS.

As in Syria, critical to sustaining the conflicts among local political actors have been regional rivalries. Qatar and Turkey, the main supporters of the Muslim Brotherhood in the Middle East, backed the Government of National Salvation. Egypt under Sissi and 
This is the accepted version of Pradella, Lucia \& Rad, Taghdisi Rad, Sahar (2017) Libya and Europe: imperialism, crisis and migration. Third World Quarterly, 1-17. Publishe online 25 July, available at: http://dx.doi.org/10.1080/01436597.2017.1350819

Accepted version downloaded from SOAS Research Online: http://eprints.soas.ac.uk/24472/

Saudi Arabia, the most determined opponents of the Brotherhood, supported the 'secular' Haftar regime. In 2015 the UN facilitated talks between factions to create the Government of National Accord (GNA) under the leadership of Favez al-Serraj, which held its first meeting in January 2016. But the infighting between the various governments continues. In September 2016 Haftar's Libyan National Army (LNA) captured major oil facilities in the gulf of Sirte (where 80 per cent of Libya's oil exports come from), taking them out of the control of the GNA-aligned factions of the Petroleum Facilities Guards. While European and US powers formally support the GNA - hoping for a channel for resuming their business activities - they have recognised Haftar's military strength and conducted informal military missions in his support, forming alliances with the Tobruk government. ${ }^{54}$ The US seems to have focused on the ISIS presence in eastern Libya: US airstrikes supported a successful operation by GNA militias to expel ISIS from the city of Sirte in December 2016. Russia, after its successful pro-Assad military intervention in Syria staked its claim to supplant the US as the regional power-broker, has also lent political and military support to Haftar in return for a share in Libya's oil, construction and infrastructural contracts. ${ }^{55}$ Since 2012 Chinese delegations have also been back, signing several lucrative contracts for housing and infrastructural projects with the Tobruk-government. ${ }^{56}$ Italy is the lead EU power in Libya. Due to the off-shore nature of its activities, ENI's production levels in Libya actually rose above the pre-2011 levels. ${ }^{57}$ In January 2017 Italy re-opened its embassy in Tripoli and reinforced its diplomatic activities also with the goal of containing Russia's increasing influence in the region.

According to UNCTAD in 2015 Libya's top five trade partners were Italy, Germany, France, China and Spain. Libya remained one of the top sources of investment in Africa 
This is the accepted version of Pradella, Lucia \& Rad, Taghdisi Rad, Sahar (2017) Libya and Europe: imperialism, crisis and migration. Third World Quarterly, 1-17. Publishe online 25 July, available at: http://dx.doi.org/10.1080/01436597.2017.1350819

Accepted version downloaded from SOAS Research Online: http://eprints.soas.ac.uk/24472/

(with $\$ 0.9$ billion investments compared to nearly \$2 billion in 2010), but overall investment inflows into Libya declined from about $\$ 2$ billion in 2010 to 725 million in 2015. From a pre-2011 average of 1.5 million bpd, oil production reached a low of $335,000 \mathrm{bpd}$ in the first half of 2016. Measured by nominal GDP, in 2015 the size of the Libyan economy was nearly two-thirds of what it was in 2010, with a current account deficit of 57 per cent and a fiscal deficit of almost 59 per cent; domestic debt reached 110 per cent of GDP in 2016 compared to 4.1 per cent in 2012. The existence of three parallel governments is making it difficult to deliver essential services to the population, and some analysts claim that only one million of the 1.8 million civil servants are receiving their salaries. While unemployment continues to rise, the de facto removal of food subsidies has led to the proliferation of black markets and an upward pressure on prices (with wheat and flour price hikes of 500 and 350 per cent respectively compared to pre-2011 levels). In 2015 almost one and a half million people were food insecure, more than 62 per cent of the population suffered from low access to health services and essential medicines, and about 150,000 children were at risk of no access to education. 'The death toll mounts,' Vijay Prashad reports, 'and refugees sit along the coastline waiting for the weather to improve. ${ }^{, 58}$

\section{Bordering the reserve army of labour}

As we have seen, the role of the reserve army of labour is central to Marx's original theory of imperialism. The Libya NATO intervention and the following civil war, economic crisis and mass impoverishment had a strong impact on the dynamics of the reserve army of labour. The 2011 conflict led to a massive displacement crisis, with about 550,000 people uprooted within the country, 660,000 seeking shelter in 
This is the accepted version of Pradella, Lucia \& Rad, Taghdisi Rad, Sahar (2017) Libya and Europe: imperialism, crisis and migration. Third World Quarterly, 1-17. Publishe online 25 July, available at: http://dx.doi.org/10.1080/01436597.2017.1350819

Accepted version downloaded from SOAS Research Online: http://eprints.soas.ac.uk/24472/

neighbouring countries and most of the 2.5 million immigrants leaving Libya. Although a majority of Libyans returned after Gaddafi's fall and immigration has partially recovered, the subsequent surge of violence engendered an unprecedented movement of population, with hundreds of thousands of suspected Gaddafi supporters leaving primarily for Tunisia and other neighbouring countries. ${ }^{59}$ Even before the 2014 civil war, militias played a crucial role in the displacement crisis by assaulting, forcing to leave and grabbing the land of, not only individuals but entire communities labelled as loyalist (e.g., Tawerghans, Ghuwalish and Werfella). In September 2016 there were 313,000 internally displaced people in Libya, 357,259 refugees and immigrants, 462,957 returnees, and 436,775 most vulnerable non-displaced Libyans; despite the almost total silence of the 'international community', the estimated numbers of Libyan exiles ranged from 500,000 to 1.5 million. ${ }^{60}$ Although the majority of Libyan exiles have not tried to move to Europe, an increasing number of emigrants and refugees primarily from Syria and the rest of Africa - transit through Libya to Europe. While in the early 2000s the number of arrivals from the Central Mediterranean route in Italy was mostly below 40,000 (only 4,300 in 2010), it reached 120,000 during the civil war and climbed to 181,000 in 2016 . In the same period, this route has become riskier and deadlier, with more than 5,000 deaths in $2016 .{ }^{61}$

Since 2011 the condition of immigrants and refugees has significantly worsened, and human smuggling has become an even more profitable and institutionalised activity. From the late 1990s onwards closer collaboration with Italy and the EU led Gaddafi to adopt a cynical attitude towards African immigrants, simultaneously welcoming them and using their presence 'to leverage billions of dollars in arms, surveillance equipment, and cash from Europeans to prevent their migration across the Mediterranean'. ${ }^{62}$ From 
This is the accepted version of Pradella, Lucia \& Rad, Taghdisi Rad, Sahar (2017) Libya and Europe: imperialism, crisis and migration. Third World Quarterly, 1-17. Publishe online 25 July, available at: http://dx.doi.org/10.1080/01436597.2017.1350819

Accepted version downloaded from SOAS Research Online: http://eprints.soas.ac.uk/24472/

the early 2000s Italy and Libya signed a series of formal agreements, and EU

institutions and single member states invested millions of euros in aid and contracts, creating joint patrols on the Libyan coasts, and collaborating on readmissions. In the 2008 Treaty of Friendship, Partnership and Co-operation - officially intended to right the wrongs of colonialism - Libya and Italy pledged to cooperate in the fight against terrorism, organised crime and 'illegal' migration. The Treaty included a $€ 5$ billion package to Libya, and assigned to Italian companies the construction of an electronic 'wall' on Libya's southern borders to be co-funded by the EU and Italy. ${ }^{63}$ This collaboration violated the principle of non-refoulement as Libya was not a state party to the 1951 Convention and only admitted the presence in its territory of economic immigrants. Libyan authorities were documented regularly to deport immigrants without checking their conditions or right to asylum; in detention centres, immigrants and refugees had no legal guarantees, and were subject to forced labour, rapes and beatings. The EU did not complain even when the Libyan authorities unilaterally shut down the UNHCR office and expelled its staff in June $2010 .^{64}$

Gaddafi, however, was reluctant fully to comply with EU policies of border controls and mass expulsion, as this could jeopardise his interests in the rest of Africa, and did not sign the Euro-Mediterranean Association Agreements (EMAA) with the EU, aimed at establishing a free-trade area and boosting cooperation on migration controls. As part of his shift to Pan-Africanism and his active role in the foundation of the Community of Sahel-Saharan States (CEN-SAD), from the early 1990s Gaddafi had implemented an open door policy towards most of Libya's African neighbours. Libya has thus become a main destination for immigrants not just from the Maghreb, but also from West Africa and the Horn of Africa. Although the process of 'externalisation' of European border 
This is the accepted version of Pradella, Lucia \& Rad, Taghdisi Rad, Sahar (2017) Libya and Europe: imperialism, crisis and migration. Third World Quarterly, 1-17. Publishe online 25 July, available at: http://dx.doi.org/10.1080/01436597.2017.1350819

Accepted version downloaded from SOAS Research Online: http://eprints.soas.ac.uk/24472/

controls led to a remarkable increase in visa restrictions for other African nationals throughout the 2000s, Libya's southern border remained extremely porous allowing for the continuous entry of low-paid immigrant workers. This was crucial to the Libyan economy and to Gaddafi's alliance with African countries and human smugglers. ${ }^{65}$

Since 2011 most of Libya's land borders have been officially closed, but since border management has been left outside the control of central authorities, their porosity has increased. ${ }^{66}$ The closure but porosity of borders have facilitated human smuggling. While before 2011 the security apparatus turned a blind eye to or was complicit with it, human smuggling is now more liberalised and closely connected with formal state institutions and militias - very often militias manage the illegal business and control the detention centres themselves. According to the UNHCR, in the summer of 2016 most detention centres in Libya were formally run by the Tripoli-based Ministry of Interior's Department for Combatting Illegal Migration but were actually under militia or mixed management. Amnesty International has revealed shocking abuses by the Libyan coastguard and at immigration detention centres, including beatings and killings, indefinite detention without legal support, harrowing torture and other ill-treatment including malnutrition, violence and sexual abuse, religious discrimination, and forced labour. $^{67}$

Despite this situation, the EU and international organizations have sought to reinforce border controls in the Mediterranean. The first discussions between EU representatives and the NTC in May 2011 also focused on border controls. Immediately after Gaddafi's execution, the NTC and Italy reactivated the Friendship Treaty article regarding the fight against 'illegal' migration. Italy-Libya cooperation was reinforced in 2013, and the EU made a commitment to supporting Libyan authorities in developing their capacity 
This is the accepted version of Pradella, Lucia \& Rad, Taghdisi Rad, Sahar (2017) Libya and Europe: imperialism, crisis and migration. Third World Quarterly, 1-17. Publishe online 25 July, available at: http://dx.doi.org/10.1080/01436597.2017.1350819

Accepted version downloaded from SOAS Research Online: http://eprints.soas.ac.uk/24472/

for enhancing border security. Control of the Libyan route became even more crucial after the 2014 civil war and the EU-Turkey deal in March 2016, which forced many emigrants to abandon the Balkan route and return to the perilous Central Mediterranean route. In May 2016 the EU announced plans to extend its anti-smuggling naval mission in the Mediterranean, Operation Sophia, and the training of the Libyan coastguard. In February 2017 EU leaders endorsed the Italian memorandum of understanding signed with Prime Minister al-Serraj aimed at 'stopping' migration from Libya and combatting the smuggling routes with Niger and Chad. Confirming the previous trend towards border externalisation, the EU is thus supporting the abhorrent human rights violations that emigrants are trying to escape in Libya. Significantly, however, the Tobruk-based parliament has refused to recognise this deal. ${ }^{68}$

\section{Conclusion}

This article analyses inter-states rivalries against the backdrop of the global process of capital accumulation, and highlights the link between economic crisis and imperialist expansion. In the wake of the global economic crisis, control on Africa and the Middle East became even more important for western powers, and the 2011 Arab uprisings represented a profound threat. In Libya, where the working class was weaker, western powers intervened militarily to promote regime-change. This was aimed at strengthening their exploitation of the country's resources, undermining the influence of Russia and China, and, above all, blocking the extension and radicalisation of the uprising. With the US turning their attention to the Pacific Rim, the NATO intervention gave France, Britain and Qatar an opportunity to assert themselves and implement an arm's length regime-change strategy. 
This is the accepted version of Pradella, Lucia \& Rad, Taghdisi Rad, Sahar (2017) Libya and Europe: imperialism, crisis and migration. Third World Quarterly, 1-17. Publishe online 25 July, available at: http://dx.doi.org/10.1080/01436597.2017.1350819

Accepted version downloaded from SOAS Research Online: http://eprints.soas.ac.uk/24472/

Planning to strengthen the neoliberal reforms already underway under Gaddafi, however, the western-backed NTC could not fulfil the popular socio-economic and political aspirations that had animated the Libyan uprising; it rather channelled social discontent towards factional fighting, unleashing a spiral of retribution and divisions. The liberal pro-western political elite, however, soon lost control of the country, as proved by the killing of the US ambassador and destruction of the CIA headquarters, the civil war and subsequent withdrawal of international actors from Libya. While the political and economic meltdown and division of the country is in line with the imperialist 'divide and rule' strategy, it is hard to distinguish any real form of political 'rule' that has been achieved. The scramble for Libya's wealth has been obstructed by security concerns and lack of political unity. Local forces acting in concert with regional actors have limited the influence of western imperialism, leaving more space for Russia, China, and regional actors.

The NATO intervention and the civil war exacerbated social divides in Libya, leading to the impoverishment of vast swathes of the population, extreme human rights abuses, and an unprecedented displacement crisis. Because of this socio-economic and political situation, including the rise in racism and racist attacks, the number of immigrants in the country has declined while the transit towards Europe of African and Syrian emigrants and refugees has increased. This has been the case especially after the EU-Turkey deal in March 2016, which forced emigrants and refugees to return from the Balkan to the Central Mediterranean route. The closure but increasing porosity of the borders between Libya and neighbouring African countries and the continuing externalisation and militarisation of the EU borders have made human smuggling an even more profitable activity, mainly managed by local militias in collaboration with state institutions. By 
This is the accepted version of Pradella, Lucia \& Rad, Taghdisi Rad, Sahar (2017) Libya and Europe: imperialism, crisis and migration. Third World Quarterly, 1-17. Publishe online 25 July, available at: http://dx.doi.org/10.1080/01436597.2017.1350819

Accepted version downloaded from SOAS Research Online: http://eprints.soas.ac.uk/24472/

continuing to support Libyan detention efforts, EU countries, starting from Italy, are deeply involved in these human rights abuses. The lack of political unity and evolving power relations in Libya, however, are limiting their control over the reserve army of labour in the region. The instability along the southern and eastern Mediterranean coastline - a product of the 2011 uprising and the different forms of political reactions they unleashed - is therefore both a channel of migratory movements and a security threat to European capitalism. 
This is the accepted version of Pradella, Lucia \& Rad, Taghdisi Rad, Sahar (2017) Libya and Europe: imperialism, crisis and migration. Third World Quarterly, 1-17. Publishe online 25 July, available at: http://dx.doi.org/10.1080/01436597.2017.1350819

Accepted version downloaded from SOAS Research Online: http://eprints.soas.ac.uk/24472/

\section{References}

Achcar, G. The People Want: A Radical Exploration of the Arab Uprising. London: Saqi Books, 2013.

African Economic Outlook (AEO). "Libya Country Note.” Tunis: African Development Bank,

Amin, S. “2011: An Arab Springtime?” In African Awakening: The Emerging Revolutions, edited by F. Manji and S. Ekine. Oxford: Pambazuka Press, 2012.

Amnesty International. EU Risks Fuelling Horrific Abuse of Refugees and Migrants in Libya, 2016.

Andrijasevic, R. "From Exception to Excess: Detention and Deportations across the Mediterranean Space." In The Deportation Regime: Sovereignty, Space and the Freedom of Movement, edited by N. De Genova and N. Peutz. Durham, NC: Duke University Press, 2010.

Anievas, A. ed. Marxism and World Politics. Abingdon and New York: Routledge.

Berkowitz, O., T. Shraga and R. Lawrence. "Libya Special Intelligence Report Projections on Stabilization and the Challenges Ahead." Max Security. August, 2016.

Bialasiewicz, L. "Off-shoring and Out-sourcing the Borders of Europe: Libya and EU Border Work in the Mediterranean." Geopolitics 17:4 (2012): 843-866.

Bieler, A. and A. Morton, A. "Axis of Evil or Access to Diesel? Spaces of New Imperialism and the Iraq War." Historical Materialism, 23, no. 2 (2015): 94-130.

Bloomberg. "Eni's Libya Output Above Pre-War Levels at 300,000 Barrels a Day”, 13 May 2015.

Bradley, M., I. Fraihat and H. Mzioudet. Libya's Displacement Crisis: Uprooted by Revolution and Civil War. Washington DC: Georgetown University Press, 2016.

Callinicos, A. "The Internationalist Case against the European Union." International Socialist Journal 2, no. 148 (2015), http://isj.org.uk/the-internationalist-case-againstthe-european-union/

Campbell, H.G. Global NATO and the Catastrophic Failure in Libya. New York: Monthly Review Press, 2013.

Cummings, C., J. Pacitto, D. Lauro and M. Foresti. "Why People Move: Understanding the Drivers and Trends of Migration to Europe". Overseas Development Institute Working Paper No. 430, 2015.

De Genova, N. "The 'Crisis' of the European Border Regime: Towards a Marxist Theory of Borders.” International Socialism, Issue 150, 2016.

De Haas, H. "The Myth of Invasion: The Inconvenient Realities of African Migration to Europe." Third World Quarterly 29, no. 7 (2008): 1305-22.

ECFR. Intervening Better: Europe's Second Chance in Libya. Policy Memo, ECFR/172, 2016.

Engdahl, F.W. "NATO's War on Libya is Directed against China: AFRICOM and the Threat to China's National Energy Security." Global Research, September 25, 2011. 
This is the accepted version of Pradella, Lucia \& Rad, Taghdisi Rad, Sahar (2017) Libya and Europe: imperialism, crisis and migration. Third World Quarterly, 1-17. Publishe online 25 July, available at: http://dx.doi.org/10.1080/01436597.2017.1350819

Accepted version downloaded from SOAS Research Online: http://eprints.soas.ac.uk/24472/

European Commission. Helping Firms Grow: European Competitiveness Report 2014. Luxembourg: European Commission DG Enterprise and Industry, 2014.

Financial Times. "How China Rules the Waves", January 12, 2017.

Fitzgerald, M. "Finding Their Place: Libya's Islamists During and After Their Revolution." In The Libyan Revolution and Its Aftermath, edited by P. Cole and B. McQuinn. New York: OUP, 2015.

Flahaux, M-L. and H. de Haas. "African Migration: Trends, Patterns, Drivers." Comparative Migration Studies 4, no. 1 (2016): 1-25.

Forte, M. Slouching towards Sirte: NATO's War on Libya and Africa. Montreal: Baraka Books, 2012.

Foster J.B., R.W. McChesney and R.J. Jonna. "The Global Reserve Army of Labor and the New Imperialism”, Monthly Review 63, no. 6 (2011).

Global Detention Project, https://www.globaldetentionproject.org/countries/africa/libya

Global Research. 'Libya's 'Water Wars' and Gaddafi`s Great Man-Made River Project.” Centre for Research on Globalization, 2013.

Hamood, S. "African Transit Migration through Libya to Europe: The Human Costs." Forced Migration and Refugee Studies. The American University of Cairo, 2006.

Hanieh, A. Lineages of Revolt: Issues of Contemporary Capitalism in the Middle East. Chicago: Haymarket Books, 2013.

Harvey, D. The New Imperialism, Oxford: Oxford University Press, 2005.

Henriksen, D. and A.K. Larssen. Political Rational and Consequences of the War in Libya. Oxford: OUP, 2016.

House of Commons Foreign Affairs Committee. "Libya: Examination of Intervention and Collapse and the UK's Future Policy Options," Third Report of Session 2016-17, 2016.

IMF. Libya Beyond the Revolution: Challenges and Opportunities, Washington DC: IMF, 2012.

IMF. IMF Executive Board Concludes 2010 Article IV Consultation with the Socialist People's Libyan Arab Jamahiriya. Public Information Notice (PIN) no. 11/23 (2011), February 15.

IMF. The Socialist People's Libyan Arab Jamahiriya - 2010 Article IV Consultation, Preliminary Conclusions of the Mission. 28 October, 2010

IOM. Displacement Tracking Matrix Libya, May-June 2016, 2016

Italian Ministry of the Interior statistics, http://www.ismu.org/\%20irregolari-e-sbarchipresenze/

Kamat, A. and A. Shokh. "Libya." In Dispatches from the Arab Spring: Understanding the New Middle East, edited by P. Amar and V. Prashad. Minneapolis: University of Minnesota Press, 2013. 
This is the accepted version of Pradella, Lucia \& Rad, Taghdisi Rad, Sahar (2017) Libya and Europe: imperialism, crisis and migration. Third World Quarterly, 1-17. Publishe online 25 July, available at: http://dx.doi.org/10.1080/01436597.2017.1350819

Accepted version downloaded from SOAS Research Online: http://eprints.soas.ac.uk/24472/

Khan, M. and K. Mezran. "Aftermath of the Arab Spring in North Africa". Atlantic Council, October 2016.

Khan, M. and Mezran, K. "The Libyan Economy after the Revolution". Atlantic Council, August 2013.

Lenin, V.I. Imperialism: The Highest Stage of Capitalism, London: Pluto, 1996.

Luxemburg, R. The Accumulation of Capital. London and New York: Routledge, 2004.

Libya Business News. "China to Invest \$36bn in Libyan Infrastructure”, 1 November 2016.

Libya Business News. "Billions in Investment Needed for Renewables", 29 July 2013.

MacDonald, A.M., H.C. Bonsor, B.E.O. Dochartaigh and R.G. Taylor. "The

Quantitative Maps of Groundwater Resources in Africa.” Environ. Res. Lett. 7, 2012.

Malakooti, A. Mixed Migration: Libya at the Crossroads. Tripoli: UNHCR, 2013.

Martinez, L. The Libyan Paradox. New York: Columbia University Press, 2007.

Marx, K. Capital: A Critique of Political Economy, Volume I. London: Penguin, 1990.

Marx, K. Capital: A Critique of Political Economy, Volume III. London: Penguin, 1981.

Mezran, K. "Libya in Transition: From Jamahiriya to Jumhūriyyah?" In The New Middle East: Protest and Revolution in the Arab World, edited by F.A. Gerges. New York: Cambridge University Press, 2013.

Norfield, T. The City: London and the Global Power of Finance. London: Verso, 2016.

OCHA. 2017 Libya Humanitarian Needs Overview. November, 2016.

Pham, J.P. “America's New Africa Command: Paradigm Shift or Step Backwards?"

The Brown Journal of World Affairs 15, no. 1 (2008): 257-272.

Pradella, L. L'attualità del Capitale: Accumulazione e impoverimento nel capitalism globale. Padua: Il Poligrafo, 2010.

Pradella, L. "Imperialism and Capitalist Development in Marx's Capital." Historical Materialism 21, n. 2 (2013): 117-47.

Prashad, V. The Death of the Nation and the Future of the Arab Revolution, California: University of California Press, 2016.

Prashad, V. "It's Bombs Away for the USA in Libya." Alternet, 3 August, 2016.

Prashad, V. (2013) Neoliberalism with Southern Characteristics: The Rise of the BRICS. New York: Rosa Luxemburg Stiftung.

Prashad, V. Arab Spring, Libyan Winter. Delhi: LeftWord Books, 2012.

Ronen, Y. “Britain's Return to Libya.” Middle Eastern Studies 59 no. 5 (2012): 675695.

Serfati, C. "Imperialism in Context: The Case of France." Historical Materialism 23, no. 2 (2015): 52-93. 
This is the accepted version of Pradella, Lucia \& Rad, Taghdisi Rad, Sahar (2017) Libya and Europe: imperialism, crisis and migration. Third World Quarterly, 1-17. Publishe online 25 July, available at: http://dx.doi.org/10.1080/01436597.2017.1350819

Accepted version downloaded from SOAS Research Online: http://eprints.soas.ac.uk/24472/

Smith, J. Imperialism in the Twenty-First Century. New York: Monthly Review Press, 2016.

St John, R.B. "The Libyan Economy in Transition". In D. Vandewalle, Libya since 1969: Qadhafi's Revolution Revisited. London: Palgrave Macmillan, 2008.

The Telegraph, "Libya Commercial Round-Up for December 2008 and January 2009" (passed by Wikileaks), 31 January 2011.

Tierney, D. “The Legacy of Obama's 'Worst Mistake'.” The Atlantic, April 15, 2016.

Toaldo, M. "Migrations through and from Libya: A Mediterranean Challenge." Instituto Affari Internazionali Working Paper. No. 15, 14 May, 2015.

UNCTAD. World Investment Report. Geneva, 2016.

UNICEF. Libya Humanitarian Situation Report. November, 2016.

UNICEF. UNICEF responds to the emerging water crisis in Tripoli. News Note, 2012.

United Nations. Detained and Dehumanized: Report on Human Rights Abuses against Migrants in Libya. UNAMIL, 13 December 2016.

Vandewalle, D. "Libya in the New Millennium", In D. Vandewalle, Libya since 1969: Qadhafi's Revolution Revisited. London: Palgrave Macmillan, 2008.

Walia, H. Undoing Border Imperialism. Oakland, CA: AK Press, 2014.

Wherey, F. "NATO's intervention." In The Libyan Revolution and its Aftermath, edited by P. Cole and B. McQuinn. New York: OUP, 2015.

Wierda, M. "Confronting Qadhafi's Legacy." In The Libyan Revolution and Its Aftermath, edited by Cole, P. and B. McQuinn. New York: OUP, 2015.

Wintour, P. "EU reaches out to Russia to broker deal with Libyan general Haftar." The Guardian, 9 February, 2017.

World Bank. Libya's Economic Outlook October 2016, World Bank Group, 2016.

World Bank. Labor Market Dynamics in Libya Reintegration for Recovery, World Bank Group, 2015.

\footnotetext{
${ }^{1}$ Campbell, Global NATO, Loc. 379.

${ }^{2}$ Bieler and Morton, "Axis of Evil"; Norfield, The City; Serfati, "Imperialism in Context"; Smith, Imperialism.

${ }^{3}$ The scant nature of the literature is partially due to lack of reliable data and political restrictions prior to 2011 and the complex political landscape since then. The first group of scholars is best represented by Campbell, Global NATO and Forte, Slouching towards Sirte; the most representative scholar of the second strand of the literature is Achcar, The People Want.

${ }^{4}$ Harvey, New Imperialism, 144; Norfield, The City; and Smith, Imperialism.

${ }^{5}$ Marx, Capital I, 727; Luxemburg, Accumulation of Capital, 108.

${ }^{6}$ Lenin, Imperialism.

${ }^{7}$ Marx, Capital III, 498; Capital I, 779.
} 
This is the accepted version of Pradella, Lucia \& Rad, Taghdisi Rad, Sahar (2017) Libya and Europe: imperialism, crisis and migration. Third World Quarterly, 1-17. Publishe online 25 July, available at: http://dx.doi.org/10.1080/01436597.2017.1350819

Accepted version downloaded from SOAS Research Online: http://eprints.soas.ac.uk/24472/

${ }^{8}$ See the contributions to Anievas, Marxism and World Politics.

${ }^{9}$ Marx, Capital I, 915.

${ }^{10}$ Marx, Capital III, 339-48.

${ }^{11}$ Marx, Capital I, 794.

${ }^{12}$ Marx, Capital I, 854-70.

${ }^{13}$ European Commission, Helping Firms Grow, 20.

${ }^{14}$ Prashad, Neoliberalism.

${ }^{15}$ Bieler and Morton, "Axis of Evil", 118.

${ }^{16}$ Callinicos, "Internationalist Case against the EU"; Serfati, "Imperialism in Context", 80.

${ }^{17}$ Pham, "America's New Africa Command"; Serfati, "Imperialism in Context", 72-73.

${ }^{18}$ Campbell, Global NATO; Engdahl, "NATO's War"; Forte, Slouching towards Sirte.

${ }^{19}$ Foster et al, "Global Reserve Army".

${ }^{20}$ Andrijasevic, "From Exception to Excess"; Bialasiewicz, "Off-shoring", 845, 848; De

Genova, "Crisis' of the European Border Regime"; Walia, Undoing Border Imperialism, 4-5.

${ }^{21}$ de Haas, "Myth of Invasion"; De Genova, “"Crisis' of the European border regime."

${ }^{22}$ Khan and Mezran, "Aftermath", 2.

${ }^{23}$ This led to close commercial and intelligence cooperation between Tripoli and Washington and London, which got a clear understanding of the nature of the Libyan opposition. Campbell, Global NATO, Loc. 887; Martinez, The Libyan Paradox, 250; Ronen, "Britain's Return”, 685; St John, "Libyan Economy", 138, 141.

${ }^{24}$ Kamat and Shokr, "Libya", 192; Vandewalle, "Libya in the New Millennium", 223-6.

${ }^{25}$ Campbell, Global NATO, Loc. 1260; Libya Business News, "Billions in Investment"; MacDonald et al, "Quantitative Maps."

${ }^{26}$ Henriksen and Larssen, Political Rational, 76, 96; Campbell, Global NATO, Loc. 284-89;

UNCTAD, World Investment Report.

${ }^{27}$ Khan and Mezran, "Aftermath"; Campbell, Global NATO, Loc. 295, 300.

${ }^{28} \mathrm{IMF}$, Executive Board Concludes.

${ }^{29}$ Amin, "2011", 292; Kamat and Shokr, "Libya", 164, 160.

${ }^{30}$ Kamat and Shokr, "Libya", 192; World Bank, Labour Market Dynamics, 21.

${ }^{31}$ de Haas, "Myth of Invasion", 1311; Malakooti, Mixed Migration, 98-100; Kamat and Shokr, "Libya", 162.

${ }^{32}$ Kamat and Shokr, "Libya", 165.

${ }^{33}$ Fitzgerald, "Finding Their Place"; Mezran, Libya in Transition, 312.

${ }^{34}$ Martinez, Libyan Paradox, 131.

${ }^{35}$ Campbell, Global NATO, Loc. 842-8, 1007. For details on the cables see The Telegraph, "Libya Commercial Round-Up".

${ }^{36}$ Global Research, "Libya's Water Wars."

${ }^{37}$ Forte, Slouching towards Sirte, 148, 159; Martinez, Libyan Paradox, 121; and Prashad, Arab Spring, 131.

${ }_{38}^{38}$ Achcar, The People Want; Mezran, Libya in Transition, 311; and Prashad, Arab Spring, 93.

${ }^{39}$ Mezran, Libya in Transition, 320; Kamat and Shokr, "Libya", 185.

${ }^{40}$ Prashad, Arab Spring, 97; Wherey, "NATO's intervention", 107.

${ }^{41}$ Despite Libya's majority ownership of it, the ABC was exempted from the US freezing of Libyan assets.

${ }^{42}$ Campbell, Global NATO, Loc. 1618, 1763, 1781.

${ }^{43}$ UNICEF, UNICEF Responds.

${ }^{44}$ Among these 36,000 Chinese workers were evacuated in the first Chinese international armed rescue mission. The Chinese acquisition of a controlling stake in Piraeus is believed to respond to a strategic need to replace Libya for their presence in the Mediterranean. Financial Times, "How China Rules."

${ }^{45}$ Kamat and Shokr, "Libya", 169.

${ }^{46}$ IMF, Libya beyond the Revolution. 
This is the accepted version of Pradella, Lucia \& Rad, Taghdisi Rad, Sahar (2017) Libya and Europe: imperialism, crisis and migration. Third World Quarterly, 1-17. Publishe online 25 July, available at: http://dx.doi.org/10.1080/01436597.2017.1350819

Accepted version downloaded from SOAS Research Online: http://eprints.soas.ac.uk/24472/

${ }^{47}$ Prashad, Death of the Nation, Loc. 2326, 2341; Wierda, "Confronting Qadhafi's Legacy", 163.

${ }^{48}$ Kamat and Shokr, "Libya", 180-87.

${ }^{49}$ Fitzgerald, "Finding their Place", 204.

${ }^{50}$ Campbell, Global NATO, Loc. 2951.

${ }^{51}$ This lack of unity is also reflected in a series of reciprocal reproaches among western powers. House of Commons, "Libya: Examination"; Prashad, "It's Bombs Away"; and Tierney, "Legacy of Obama's Worst Mistake."

${ }^{52}$ Wierda, "Confronting Qadhafi's Legacy", 161. This law has since been repealed by the government in Tobruk.

${ }_{53}$ Given the reduced chances of conducting legal business in the country, most contracts after 2014 have been agreed in secret or on an ad hoc basis, partially explaining the difficulties in obtaining clear data on investment trends from UNCTAD, IMF and World Bank.

${ }^{54}$ Berkowitz et al, "Libya Special Intelligence"; ECFR, Intervening Better.

${ }^{55}$ Prashad, "It's Bombs Way."

${ }^{56}$ Libya Business News, "China to Invest".

${ }^{57}$ Bloomberg, "ENI's Libya Output".

${ }^{58}$ AEO, Libya Country Note, 4; Khan and Mezran, "Aftermath"; OCHA, 2017 Libya, 8;

Prashad, Death of the Nation, Loc. 2310; World Bank, Libya's Economic Outlook.

${ }^{59}$ Bradley et al. Libya's Displacement Crisis, Loc. 54 and 907; Cummings et al, "Why People Move"; Malakooti, Mixed Migration; Toaldo, "Migrations".

${ }^{60}$ OCHA, 2017 Libya; Bradley et al. Libya's Displacement Crisis, Loc. 54, 907, 974 and 1205.

${ }^{61}$ IOM, Displacement Tracking, 1, 19-20; Italian Ministry of the Interior statistics.

${ }^{62}$ Kamat and Shokr, "Libya", 163.

${ }^{63}$ Bialasewicz, "Off-shoring", 859.

${ }^{64}$ Amnesty International, EU Risks; Global Detention Project; UNICEF, Libya Humanitarian Situation.

${ }^{65}$ Flahaux and de Hass, "African Migration”, 19; Hamood, “African Transit”; Malakooti Mixed Migration, 96; Toaldo, "Migrations", 6.

${ }^{66}$ Malakooti Mixed Migration, 96.

${ }^{67}$ Amnesty International, EU Risks.

${ }^{68}$ Wintour, "EU reaches out to Russia". 